\title{
ЗАБОЛОТНЮК В.I.
}

\section{УКРАЇНСЬКА ВІЙСЬКОВО-САНІТАРНА МІСІЯ ДЛЯ СПРАВ ПОЛОНЕНИХ У НПМЕЧЧИНІ (1918-1920)}

У статті розглядається діяльність Української військово-санітарної місії для справ полонених у Німеччині у 1918-1920 рр. Окрім основного завдання - репатріації полонених українців на батьківщину та надання їм медичної та матеріальної допомоги місія займалася національною просвітницькою діяльністю серед вояків-українщів колишньої царської російської армії.

Ключові слова: Перша світова війна, військовополонені, репатріація, військово-санітарні місіі, Червоний Хрест, українсько-німецькі стосунки, військова еміграція.

Постановка та актуальність проблеми. У роки Першої світової війни у Німеччині опинилося десятки тисяч військово-полонених колишньої російської армії, які були українцями за походженням. Після утворення Української держави постало питання репатріащії полонених і надання їм медичної та матеріальної допомоги, їх організованого повернення в Україну. Актуальність ціеї теми посилюеться тим фрактом, що сьогодні, коли внаслідок Антитерористичної операції на Сході України, в полон потрапили сотні вояків Збройних Сил України, питання їх репатріації через гуманітарні інституції $є$ серед ключових завдань украӥнського уряду.

Ступінь дослідження проблеми. Про діяльність Української військово-санітарної місії у справах полонених у Німеччині згадували у своїх працях Симон Наріжний [1], Володимир Трембіцький [2-5], Василь Даниленко та Наталія Кривещь [6], Ігор Срібняк [7] та Любов Жванко [8]. У роботах Івана Патера [9], Лідії Кривошеєвої [10-11] та Йосипа Саєвича [12] досліджено національно-просвітну діяльність серед військовополонених українців у таборах

Заболотнюк Володимир Іванович - провідний науковий співробітник Наукового центру, Національна академія сухопутних військ імені гетьмана Петра Сагайдачного, м. Львів.

(C) Заболотнюк B.I., 2017 
Німеччини у роки Першої світової війни, яку проводили Зслідженнях Надії Кулеші [13] та Михайла Мартинюка [14] знаходимо інформацію про періодичні видання та публікації для українських полонених у Німеччині. Втім узагальнювального дослідження про роботу Української військової санітарної місії в Німеччині у 1918-1920 рр. досі немає.

Метою автора цієї статті було висвітлити діяльність Української військової санітарної місії в Німеччині з репатріації полонених українців та надання їм матеріальної та медичної допомоги у 1918-1920 рр. у контексті національно-визвольних змагань.

Джерелом дослідження послужили опубліковані документи [15-19], українська еміграційна преса в Австрії та Німеччині [21-25], спогади Василя Сімовича [26] та архівні документи [27-28].

Виклад основного матеріалу дослідження. У роки Першої світової війни в Німеччині опинилися десятки тисяч полонених-українців, колишніх вояків армї царської Росії. Hiмецька влада розташувала полонених у спеціальних концтаборах країни: Барделегон, Гамельн, Губен, Ерлянген, Зальцведель, Зольтав, Кведлінбург, Котбус, Нейгамер, Франфуркт на Одері, Штаргард, Штардард, Целлє, Цербст, Рулебен, Заган, Хемніц, Мерзебург, Пархім [26, с. 212213; 19, с. 30]. Загалом у таборах полонених в Німеччині, за даними Йосипа Саєвича, було сконцентровано понад 60 тис. українщів [12, с. 10]. Умови перебування полоненихукраїнців були вкрай важкими. Нерідко з них формували робітничі бригади й відправляли на примусову працю на вугільні шахти, промислові підприемства чи в сільськогосподарську сферу. Полонені працювали по 12 годин із мізерним і малокалорійним харчуванням [27, арк. 26, 28].

Революційні події в Україні наприкінці світової війни спонукали українські уряди звернути увагу на полоненихукраїнщів поза межами держави й подбати щодо їх репатріації. Зокрема, утворити спеціальну військово-санітарну місію (далі ВСМ) і направити їі до Німеччини. Метою місії була організація відправки полонених в Україну i 
матеріальна та медична допомога їм [26, с. 212]. Як стверджував В. Трембіцький, 10 березня 1918 р. уперше було відправлено ВСМ в Німеччину на чолі 3 сотником Сергієм Сиротенком і значковим Василем Байдою для перевірки стану полонених українського походження колишньої російської армії з метою організації репатріації українських полонених в Україну для поповнення місцевих військових частин [5, с. 32]. В інших джерелах немає відомості про Місію у такому складі. Можна припустити, що вказана місія мала ознайомчий характер.

Натомість документи свідчать, що 6 серпня 1918 р. Головний Штаб Військового Міністерства Української Держави видав таємну інструкцію для Місії в Німеччині. Як виходить з цього документу офіційна назва місії в 1918 р. звучала так «Військово-Санітарна комісія Українського військового Міністерства для справ військових полонених у Німеччині», гербова печатка місії мала напис: «ВійськовоСанітарна місія У. В. М. у Німеччині» [19, с. 71]. У першому параграфі інструкщії йшлося: «Місія засновується для прискорення обліку полонених та Державної допомоги полоненим українським громадянам для повернення їх у рідний край». Далі йшлося про такі завдання Місії: об’їжджати усі табори, де утримувалися українські полонені; надавати їм санітарну моральну й, при змозі, матеріальну допомогу; організовувати за можливості негайну відправку полонених в Україну [19, с. 70].

Голова Товариства Українського Червоного Хреста (далі УЧХ) д-р Андрій Окопенко призначив головою ВСМ Костя Воєвідку [2, с. 20], який залишився на своїй посаді й після повалення уряду Павла Скоропадського і приходу до влади Директорії УНР.

Персональний склад працівників Miсiї не мав постійного характеру. Стосовно нього маємо різну інформацію. Зокрема, за офріційним документом, станом на 20 липня 1919 р. перелік співробітників виглядав таким чином:

1. Воєвідка Кость - голова Miciї (місячний оклад 3500 німецьких марок). 
2. Журавель Андрій - заступник голови й старший лікар (3000 марок).

3. Сімович Василь - завідувач Культурно-просвітницьким відділом (2700 марок).

4. Паращук Михайло - завідуючий Господарським відділом (2700 марок).

5. Петренко Грицько - завідуючий Інформаційно-статистичним відділом (2700 марок).

6. Трезвінський Микола - старший діловод (скарбник) (2600 марок).

7. Гайворонський Іван - молодший лікар (2400 марок).

8. Вишневський Дмитро - бухгалтер (1600 марок).

9. Власюк Василь - співробітник Секретаріату та Інформаційно-статистичного відділу (1000 марок).

10. Вриль Роза - співробітник Секретаріату та Інформаційно-статистичного відділу (650 марок).

11. Гербст Олена - співробітник Секретаріату та Iнформаційно-статистичного відділу (650 марок).

12. Романовський Павло - співробітник Секретаріату та Інформаційно-статистичного відділу (800 марок).

13. Гаазе Марія - співробітник Секретаріату та Інформаційно-статистичного відділу (650 марок).

14. Кніпфер Сва - співробітник Секретаріату та Інформаційно-статистичного відділу (650 марок).

15. Біличенко Михайло - співробітник Культурно-просвітницького відділу (1200 марок).

16. Бачинський Микола - старшина для доручень (1100 марок).

17. Роменський Павло - кур'єр (1100 марок).

18. Кузеля Зенон - головний редактор часопису «Шлях» і представник місї̈ в таборі Зальцведель (2000 марок).

19. Терлецький Омелян - співробітник часопису «Шлях» (1200 марок) [19, с. 194-195].

Як бачимо, до складу Місії увійшли колишні діячі Союзу визволення України (З. Кузеля, В.Сімович), які вже мали досвід роботи з полоненими [10, с. 94-97].

Про склад Miciї в жовтні 1919 р. можна судити з Акта присяги на вірність Українській Народній Республіці (далі 
УНР), де зазначені члени Мiciї, які склали присягу разом з працівниками українського посольства в Німеччині. Зокрема, в Акті перелічені наступні члени Місії: військовий старшина: (др. К. Воєвідка); лікарі (А. Журавель, др. О. Суховерський); військові урядовці (М. Бачинський, П. Романовський, Д. Вишневський, М. Біліченко, В. Власюк, А. Михайленко, I. Тарануха) [19, с. 226]. Вагу членів Місї засвідчує той фракт, що четверо його членів увійшли до керівництва товариства «Українська Громада»в Німеччині [21, с. 135].

У січні 1920 р. віденський часопис «Воля» повідомив, що за наказом Головного Отамана головою ВСМ в Берліні, замість К. Воєвідки, призначено сотника Миколу Трезвінського. Однак останній кілька місяців виїхав в Україну й не поспішав повертатися [23, с. 183]. Микола Порш у листі до С. Петлюри від 25 травня 1920 р. вказав, що відкликання К. Воєвідки «не відповідає своїй цілі»[15, с. 724]. Проте С. Петлюра не відмінив наказу, й М. Трезвінський очолював Місію до часу їі ліквідації [19, с. 306].

Надані українським урядом кошти, які були в розпорядженні Місії, спрямовувалися насамперед на відправку полонених в Україну, що було першим обов'язком Miciї. Менші кошти, яких відтак бракувало, спрямовувалися на культурно-просвітницьку роботу 3 метою національного освідомлення українців [26, с. 214].

Голова місії сотник М. Трезвінський 6 лютого 1920 р. подав до уряду УНР кошторис, в якому обгрунтував фрінансові потреби місії на суму 500500 німецьких марок. В результаті, С. Петлюра підписав наказ, в якому доручалося Міністрові фрінансів Борисові Мартосу та Фінансовому агентові Супрунові видати на руки голови Місії триста тисяч німецьких марок [17, с. 183].

У липні 1919 р. Місія надала таку допомогу українським комітетам і таборам: Зальцведель - 10000 німецьких марок, Зольтав - 4000, Гаммельн - 4 000, Цербст - 2 000, Франфруркт - 1 000, Рулебен - 200, Заган - 1 500, Кведлінбург 5 000, Штаргард - 4 000, Котбус - 1 500, Хемніц - 500, Мерзебург - 800, Пархім - 1800 [6, с. 190-191]. 
Грошову допомогу українським полоненим надавала не тільки Місія, але й український уряд. У постанові Директорії УНР від 16 жовтня 1919 р. йшлося про видачу делегатам, які прибули з таборів полонених у Німеччині (Петро Бондаренко, Тиміш Курський, Лука Волюх та Іван Усенко), допомоги в сумі шістнадцять тисяч гривень (по чотири тисячі кожному) з «фонду допомог Директорії» [17, c. 129].

Місія утримувала в таборах чотирьох лікарів: двох у Зальцведелі, по одному в Барделегоні та Котбусі [26, с. 213].

У серпні 1919 р. з Киева до Німеччини з метою гуманітарної допомоги українським полоненим вирушила Місія УЧХ. Місія складалася з 49 осіб персоналу - лікарів, медсестер та санітарів. Місія привезла з собою кілька вагонів борошна, сала та інших продуктів, а також білизни для облаштування лазаретів. Завданням Місії було опіка над хворими полоненими, а також продовольчо-лікарська допомога при відправленні їх на батьківщину. 3 цією метою Місія УЧХ організувала окрему станицю в Берліні (Neue Königstr, 21, біля Alexanderplatz) й надавала лікарську допомогу більшим Українським Громадам у таборах Німеччини. Місія направила своїх лікарів до таборів полонених, які працювали в тамтешніх лазаретах. Зокрема, у Зальцведелі лікарську допомогу хворим надавав П. Клинищький, у Золтаві - Андрій Іскра, у Містені - Павло Ткачук, у Мінстері - Ольга Карчевська, у Штаргарді - Кость Бризгун [22, с. 135]. Канцелярія Місії УЧХ у Берліні розташувалася за адресою: Mission des Ukrainischen «Roten Kreuzes» in Berlin, W. Eisenacherstr. 10 [Воля, с. 135]. Усього для надання лікарської допомоги в таборах Німеччини, Італії, Австрії, Чехословаччини та Румунії самих лише фахових лікарів виїхало 42 особи [3, с. 19].

В. Трембіцький досить критично поставився до виїзду такої кількості медичного персоналу у Західну Європу в рамках УЧХ. Він з цього приводу відзначив: «Ясно, туди попадало багато таких лікарів, яких присутність за кордоном була зайвою, а виїжджаючи туди, ті лікарі мали на увазі тільки власний, зрештою, зрозумілий інтерес: рятувати 
себе і свої родини від лих війни та від пошести тифу, який жахливо нищив не лише вояцтво, а й лікарів у польових шпиталях»[3, с. 19]. Берлінський відділ УЧХ, як і Місія для справ полонених, також провадив культурно-освітню працю між полоненими-українцями, й мав у німецькій столиці свою бібліотеку й «випозичальню» [1, с. 99].

Місія Українського Червоного Хреста під головуванням д-ра П. Холодного працювала у Німеччині протягом року. На перехідній станиці усім полоненим, які поверталися додому, надали матеріальну та лікарську допомогу [20, с. 483].

3 Місією ЧХ у Берліні пов'язана організація санітарномедичної експедиції в Україну під керівництвом Міжнародного Червоного Хреста. Виконувач обов'язків голови Ради Народних Міністрів УНР Андрій Лівицький 9 березня 1920 р. підписав постанову про асигнування двох мільйонів австрійських корон для тримісячного утримання такої експедиції на руки генерального делегата МЧХ д-ра Е. Фріка. У постанові було вказано, що у разі виплати вказаної суми відповідним еквівалентом у німецькій валюті асигновка мала бути видана міністром фрінансів на Берлін [16, с. 606]. Відомо, що П. Холодний закупив у Берліні, від імені Місії УЧХ три вагони медикаментів для відправки в Україну [25, с. 2].

Початок праці з формування у полонених українців національно-патріотичного світогляду було покладено в роки Першої світової війни співробітниками СВУ [11, с. 9 - 14; 12, с. 11-13]. Не маючи змоги домогтися в німецького уряду концентрації українців у великих таборах, Місія намагалася засновувати усюди «Українські Громади», які мали завданням організовувати українських полонених та освідомлювати їх національно [26, с. 212].

Василь Сімович згадував: «Де тільки можна було Місія скуповувала книжки, але-ж їх капля в морі супроти дійсних потреб. Попит на українську книжку незвичайно великий; всі книжечки, що їх повисилала Місія до громад, давно попрочитувано, так, що духові потреби українського 
полоненого мусить задовольняти українська газета, яку місія видає двічі на тиждень у Зальцведелі» [26, с. 213]. Йшлося про часопис «Шлях». Наклад газети був 5000 примірників [14, с. 243].

Щоб заповнити нестачу літератури місія почала видавати науково-популярну серію бібліотеки «Шлях». Станом на січень 1919 р. у серії вийшли друком такі брошури: «Як стати по українському грамотним» (В. Верниволя); «Українські політичні партії» (П. Гай'івський); «Аретметичні правила для початкових шкіл» (Я. Чепіга); «Як вести збори» (В. Немова) [26, с. 213]. У листопаді члени Мiciї В. Симович та А. Журавель приїзджали до Відня з метою закупівлі книжок для полонених-українців у Німеччині [21, с. 135].

Місія матеріально та організаційно підтримувала самодіяльні театри у таборах: Гамельн, Зальцведель, Кведлінбург, Штардард, Цербст й допомагала театрам у таборах: Губен, Зольтав, Франфуркт на Одері, Целлє; українським драматичним гурткам у місцевостях: Гамельн, Губен, Штаргард та Целле [26, с. 212]. Місія утримувала також школи в таборах Ерлянген, Зальцведель, Нейгамер, Цербст [26, с. 212].

Місія окрім таборів полонених контактувала також 3 українськими робітничими колоніями в містах Бремен, Гемелінген та Делњменюрг, де влаштувала школу для дітей робітників, а також неписемних робітників і робітниць й утримувала там вчителя [26, с. 213].

До Місї зверталися й іноземні вояки-полонені та агенти. 6 лютого 1920 р. Головний отаман у листі до Міністерства закордонних справ застерігав: «У сучасний момент помічаєтъся великий наплив до наших Військово-Санітарних місій i військових агентів козаків і старшин Бермонтовської, Авалової та інших реакційних армійських підрозділів, які як українці жадають нашої опіки, зглядно стараються увійти в склад Місій або через них до Української Армії»[17, c. 182].

Після вибуху революції у Німеччині та антигетьманського повстання в Україні справа з відправкою полонених 
на батьківщину значно просунулася вперед. До 14 січня 1919 р. Місія в порозумінні з урядом Німеччини зуміла відправити додому близько 40000 полонених українців [26, с. 212]. Надалі виїзд полонених українців з Німеччини мав значно менші масштаби. Про що свідчить дані керівника українського відділу Червоного Хреста у Відні К. Чайки за період з грудня 1919 по жовтень 1920 р. Зокрема, у грудні 1919 р. з Німеччини через Австрію в Україну виїхало 272 особи; у січні - 10 колишніх полонених; у лютому - 27, у березні - 22; у квітні - 24; у травні - 29; у червні - 50; у липні - 11; у серпні - 2; у вересні - жодного; у жовтні - 3. Усього за вказаний період Німеччину покинули 450 колишніх полонених [20, с. 484].

Слід додати, що полонені, яких було відправлено 3 Німеччини переїздили через українську збірну станицю у Відні, де їм також надавали допомогу [23, с. 166-168].

Через проблеми з фінансами навесні 1920 р. уряд УНР був змушений поступово скорочувати штати своїх закордонних місій та представництв. У наказі Української ВСМ для допомоги полоненим в Середній і Південній Свропі від 23 березня 1920 р. йшлося: «Радника Української ВійськовоСанітарної місії для справ полонених у Німеччині і завідуючого їі культурно-просвітньою секцією д-ра Василя Сімовича належить числити 3 днем 5 березня ц. р. звільненим із служби при згаданій вище Miciї і відкомандированим в розпорядження Військового Міністерства» [28, арк. 206]. Підставою для звільнення був рапорт В. Сімовича від 2 березня 1920 р. [28, арк. 206]. 9 квітня 1920 р. Посольство УНР в Німеччині направило запит на ім'я голови Miciї М. Трезвінського. В запиті вимагалося негайно надати письмову відповідь на такі питання: 1) Загальний план праці Miciï; 2) Спеціальні завдання їй довірені; 3) План евакуації, який реалізовує місія; 4) Реальні можливості реалізації цих завдань [19, с. 272].

Однак посольство не бажало зволікати, й того ж дня сотник Трезвінський отримав від посла таке розпорядження щодо скорочення штату Miciї: ß огляду на невияснений 
стан державних фінансів і малу надію на можливість дальшого фінансування Місій УНР в Німеччині пропоную Вам негайно відкомандирувати всіх членів і урядовців до Військового міністерства на Україну із виїмком найпотрібніших» [19, с. 273].

13 липня 1920 р. посольство повідомило Трезвінського про те, що частково функції виконував УЧХ. В результаті фрункщії Місії перебрало на себе посольство УНР у Німеччині. У листі на ім'я голови Місії було сказано: ЩПосольство УНР в Німеччині перебирає на себе слідуючі точки: а) евакуащія полонених; г) захист інтересів полонених; б) культурнопросвітна робота буде обмежена на видання часописів, при чім всі книжки і бібліотеки будуть по можності залишені громадам» [19, с. 306].

Посольство повідомило, що з 15 липня офіційно повідомить німецький уряд про припинення діяльності Місії. Посольство звернулося до М. Трезвінського і його заступника повернути німецькі посвідчення («легітимаційні картки») [19, с. 306].

Проте процес ліквідації Місії ще деякий час тривав. Опублікований в збірнику документ, датований 26 липня 1920 р., свідчить про такі виплати Місії: платня службовцям за червень 1920 р.; платня лікареві Гайворонському; платня учителеві М. Поліщукові за 8 днів праці у школах робітничої колонії; допомога співробітникові Власюкові на лікування; покриття позичок місії у приватних осіб; видатки по лазарету у Зальщведелі; плата за позичене майно Комітетові культурної допомоги; плата за часопис «Україна» згідно з рахунком німецько-української Громади; платня «порте» за липень 1920 р.; транспортування майна із Вецляра до Берліна згідно рахунку фрірми «А. Вармут» (595, 50 марок). Усього виплат на суму 27 538, 15 марок) [19, с. 309]. Ліквідована була не тільки місія в Німеччині. 14 серпня 1920 р. Рада Міністрів УНР ухвалила постанову про ліквідацію ВСМ для справ полонених в Центральній та Південній Свропі і про передачу справи допомоги 
полоненим українцям від Міністерства військових справ до Міністерства закордонних справ УНР [19, с. 314-315].

С. Наріжний стверджував, що у 1921 р. німецький уряд легалізував Місію, як і відділ УЧХ [1, с. 99]. Очевидно тут закралася помилка, бо, як бачимо, того року Місія в Берліні вже не існувала.

Висновки. Утворення Української військово-санітарної місії в Німеччині місї було викликане насамперед потребою репатріації полонених-українців. Втім Місія розвинула набагато ширшу діяльність. Ї̈̈ працівники продовжили працю 3 національно-просвітної діяльності серед полонених, яку започаткували в роки Першої світової війни співробітники Союзу визволення України. Займалася нащіональним освідомленням полонених, видавала часопис та українські популярні книжки, утримувала театральні гуртки. Робота Miсії здійснювалася у координації з українським посольством у Німеччині та представництвом Червоного Хреста. Українська військово-санітарна місія припинила свою діяльність через брак коштів, проте зуміла в основному виконати, своє основне призначення.

1. Наріжний $C$. Українська еміграція. Культурна праця української емігращії 1919-1939 (матеріали, зібрані С. Наріжним до частини другої) / Симон Наріжний. К.: Видавництво імені Олени Теліги, 1999. - 272 с.

2. Трембщький B. Всеукраїнське Товариство Червоного Хреста 1918-1923 / Володимир Трембіџький // Вісті Комбатанта. - Торонто; Нью-Йорк, 1972. - Ч. 4. C. 16-21.

3. Трембіцький В. Лікарський світ за української держави (за Директорії 1919-20 р.) / Володимир Трембіцький // Вісті Комбатанта. - Торонто-Нью-Йорк, 1974. Ч. 1. - C. 18-21.

4. Трембіцький В. Міністерство Здоров'я в УНР / Володимир Трембіщький // Вісті Комбатанта. - Торонто; Нью-Йорк, 1972. - Ч. 3. - С. 14-21.

5. Трембіцький В. Основи Санітарно-медичної служби в УНР (листопад 1917- березень 1918) - Ч. 1. / Володимир Трембіщький // Вісті Комбатанта. - ТоронтоНью-Йорк, 1972.- С. 29-32.

6. Даниленко В., Кривець Н. Передмова / Василь Даниленко, Наталія Кривець // Українські дипломатичні 
представництва в Німеччині (1918-1922): Документи і матеріали / Упор. В. М. Даниленко, Н. В. Кравець. К.: Смолоскип, 2012. - С. 5-45.

7. Срібняк I. Обеззброєна, але нескорена: Інтернована Армія УНР в таборах Польщі і Румунії (1921-1924 рр.) / Ігор Срібняк. - Київ; Філадельфія, 1997.

8. Жванко Л. Соціальні виміри Української Держави (квітень-грудень 1918 р.) / Любов Жванко. - Харків: Прапор, 2007. - 224 с.

9. Патер Іван. Союз визволення України: проблеми державності і соборності / Іван Патер. - Львів: Інститут українознавства ім. І.Крип'якевича НАН України, 2000. - $346 \mathrm{c}$.

10. Кривошеєва Л. М. Діяльність Василя Сімовича в організації таборової преси / Лідія Миколаївна Кривошеєва // Українська журналістика в контексті доб: Матеріали всеукр. наук.-практ. конференції. Львів, 2324 вересня 2004 р. - Львів: ЛНУ, 2004. - С. 94-97.

11. Кривошеєва Л. М. Національно-просвітня діяльність Союзу Визволення України в таборах військовополонених українців /Авторефр. дис. канд. іст. наук. Запоріжжя, 2009. - 16 с.

12. Саєвич Й. Й. Військовополонені українці в таборах Австро-Угоршини і Німеччини в період Першої світової війни: вишкіл та організація побуту / Автореф. дис. канд. іст. наук. - Львів, 2007. - 20 с.

13 Кулеша Н. М. Українська преса у Німеччині 1919-1945 рр.: формування та функціонування: монографія / Надія Кулеша / НАН України, ЛННБУ ім. В. Стефраника, Відділення «Науково-дослідний центр періодики». - Львів, 2009. - 344 с.

14. Мартинюк $M$. Українські періодичні видання Західної України, країн Центральної та Західної Свропи (1914-1939 рр.): матеріали до бібліографії / Михайло Мартинюк / Передмова М. Вальо. - Львів, 1998. - 298 с.

15. Архів Української Народної Республіки. Міністерство закордонних справ. Дипломатичні документи від Версальського до Ризького мирних договорів (1919-1921) / Упор. Валентин Кавунник. - К.: Інститут української археографії та джерелознавства ім. М. С. Грушевського, 2016. - 796 с.

16. Директорія, Рада Народних Міністрів Української Народної Республіки 1918-1920. Документи і матеріали у 2 томах /Відп. ред. В. Верстюк. - К.: Вид־во імені Олени Теліги, 2006. - Т. 2. - 744 с. 
17. Симон Петлюра. Статті, листи, документи. Т. ІІІ / Упорядник В. Сергійчук. - К.: Вид-во імені Олени Теліги, 1999. - 616 с.

18. Українська політична еміграція 1919-1945: Документи і матеріали. - К.: Парламентське вид-во, 2008. - 928 c.

19. Українські дипломатичні представництва в Німеччині (1918-1922): Документи і матеріали / Упор. В. М. Даниленко, Н. В. Кравець. - К.: Смолоскип, 2012. 592 с.: іл.

20. Чайка $K$. Український Червоний Хрест за кордоном // Воля. - Відень, 1920. - 4 грудня. - Т. 4. - Ч. 10. С. $482-486$.

21. Воля. - Відень, 1919. 15 листопад. Т. 5. Ч. 3. C. $135-137$.

22. Воля. - 1919. - 16 серпня. - Т. 2. - Ч. 3. C. $135-136$.

23. Воля. - 1920. - 24 січня. - Т. 1. - Ч. 4. - С. 182-184.

24. Воля. - 1920. - 24 січня. - Т. 1. - Ч. 4. С. 166-171.

25. Український Прапор. - Відень, 1920. - 20 червня. Ч. 36. - C. 2.

26. Верниволя В. [Сімович В.]. Українська військовосанітарна Місія в Німеччині / Василь Верниволя // Воля. Відень, 1919. - 29 листопада. - Т. 5. - Ч. 5. С. 212-214.

27. Центральний державний історичний архів України у Львові (далі - ЦДІАУЛ), ф. 581 (Колекція документів діяльності уряді та армій УНР і ЗУНР), оп. 1, спр. 196. - 38 арк.

28. ЦДІАУЛ, ф. 581, оп. 1, спр. 199. - 212 арк.

Надійшла до редколегії 30.08.2017 p.

Рецензент: Л.О. Клебан, кандидат історичних наук, зберігач фондів Археологічного музею історичного факультету Львівського національного університету імені Івана Франка, м. Львів.

\section{Zabolotnyuk Volodimir \\ UKRAINIAN MILITARY SANITARY MISSION FOR MILITARY PRISONERS IN GERMANY (1918-1920)}

The article deals with the activities of the Ukrainian Military Sanitary Mission on matters of prisoners of war in Germany in 1918-1920. In addition to the main task of repatriating Ukrainian prisoners of war to their homeland and providing them with medical and material assistance, the mission was engaged in the national education of the Ukrainian soldiers of the former tsarist Russian army.

Keywords: World War I, prisoners of war, repatriation, Military Sanitary Missions, the Red Cross, Ukrainian-German relations, military emigration. 